\title{
Education and the Paradox of Graduate Unemployment and Employability in Nigeria
}

$$
\text { Olabiyi, O.B }{ }^{1}
$$

\begin{abstract}
The Nigerian society has been faced with the menace of unemployment over the recent years. However this was not the case when Higher Education was introduced to the Nigerian society. The society at that time adapted education as a tool for social change and social mobility. Education paved way for people to gain employment with government and private firms. Hence, the Nigerian society benefited immensely from Higher Education which paved way for peace and tranquility to thrive. Nonetheless, today the society is faced with the challenge of unemployment and it has become a concern not just because unemployment has ravaged the Nigerian society but because University graduates have been found lacking skills that are necessary for employment. The Unemployment challenge has led many graduates into cybercrimes, armed robbery, kidnapping and diabolic means of getting wealthy. The Universities have contributed to this situation merely by churning out a flood of graduates that are unskilled and unemployable. This article hence examines graduate unemployment in Nigeria and recommends that Universities curriculum be tailored to meet specific skills required in the society, work study program be incorporated into higher education, and National Youth Service Corps (NYSC) be incorporated with the National Directorate of Employment (NDE) as an employment route for graduates in order to help recreate the peace and tranquility that Nigeria enjoyed earlier.
\end{abstract}

Keywords: Higher Education, Graduate, Unemployment, Employability, Employment, Government, Nigeria.

\footnotetext{
${ }^{1}$ Olabiyi, O.B is with Department of Educational Foundations, University of Lagos, Lagos Nigeria.
} 


\section{Education and the Paradox of Graduate Unemployment and Employability in Nigeria}

\section{Introduction}

The university is the highest tertiary institution that is charged with the responsibility of disseminating knowledge and skills to students with the aim of equipping them with middle and high level manpower and as such students can successively take up roles within the society and be ready to utilize their learnt skills for the growth and development of their nation and themselves. Hence the University ab initio functions for public and private good.

Academic degrees are awarded as an evidence of completing an academic programme in a given discipline. The capacity of a nation to adopt, disseminate and maximize rapid technological advancement is essentially hooked to its university education. This is often because knowledge and intellectual skills are critical determinants of economic process and development in any society. Those that acquire university education are expected to secure employment in areas associated with their knowledge and skills and this enables them live above poverty line.

With the emergence of university education, one expects that each person who is in a position to have received a university degree should be able to secure employment from available employment opportunities as this may successively transform and enhance his or her quality of life. However, this is often a far cry from reality in Nigeria and therefore the shocking paradox is that folks with university degrees roam the road for years after graduation in search of jobs, frustration and desperation sometimes lead graduates to either secure menial jobs as drivers, barbers, sales rep, or lower jobs so as to meet up with survival expectations. Others however result in adopting to crime and other fast means of accumulating wealth to be able to cope within the society today. Many graduates have been involved in robbery, cyber fraud, kidnapping and other social menace due to the necessity of livelihood which had not been provided for them by the government. Nonetheless, there is no justification for committing crimes hence it becomes imperative that we address the issue of unemployment in our society so as to recreate the peace and tranquility we once enjoyed. In critiquing the menace of graduate unemployment and employability in Nigeria, it is imperative that we examine the roles government has played in creating more unemployed graduates over the years, even though the universities are saddled with the responsibility of equipping students with skills needed for them to function in the larger society. They have also rather contributed 
hazardously by creating a lot of unemployable graduates making the society having to grapple with governments' lackadaisical attitude in creating jobs for graduates and the universities failure in training highly skilled graduates. Instead, what we have witnessed over time has been that graduates are usually not equipped with the most relevant skill needed for them to function in today's society. The universities in most cases run a repeated old fashioned curriculum and while society is changing and advancing in the use of new technologies and methodologies of operations. Students are being taught same things year in year out and in reality by the time they graduate majority becomes unfit to play a role in the society because they do not possess today's requisite skills. Hence it becomes difficult for highly competitive companies to hire recent unexperienced graduates, for after all the university did not equip them with relevant skills and a lot of companies do not have the luxury to invest in "on-the-job" trainings anymore.

\section{Graduate Unemployment in Nigeria}

Graduate unemployment has become a very daunting challenge in Nigeria. Balogun (2016) hinted that nearly half the 10 million graduates churned out of the over 668 universities in Africa every yearl don't get jobs. This by implication indicates that graduate unemployment is one among the foremost critical developmental problems facing the African continent. It has to a large extent hindered many countries from achieving the Sustainable Development Goals.

In Nigeria, the dilemma of graduate unemployment has reached an alarming state. Akintoye (2008) indicated that graduate unemployment percentage rose in Nigeria from 1\% in 1974 to 4\% in 1984. However, just within a decade, between 1992 and 1997, 32\% of the unemployed graduate was accounted for within the country (Dabalen, Oni and Adekola 2000). Conservatively, Eneji, MaiLaifa and Weiping (2013) indicated the rate of unemployed graduate's percentage to be about $60 \%$ of the Nigeria labour supply market. Recent data supplied by National Bureau of Statistics (2016) indicated that about 52 million citizens within the economically active population of Nigeria are jobless and this figure consisted mostly of newly qualified university graduates.

Nigeria seems to be a country that does not have the capacity of providing employment opportunities to a considerable number of her trained university graduates. Consistent with Afolabi, Yusuf and Idowu (2014), of all the issues facing Nigeria in recent time, none is as virulent, persistent and agonizing as the problems of high unemployment among Nigerian graduates. Apart 
from being an enormous waste of human capital and loss of investment in education, those caught within the web of this social menace are often vulnerable to frustration and non-conforming behaviours. Baku, Ashiaagbor, Simon and Alfred (2008) opined that:

rampant unemployment of university graduates is not only a disincentive to schooling, but could even be a recipe for social unrest, if not checked. For these reasons, reducing the issues of graduate unemployment in Nigeria is perhaps tantamount to solving one amongst the several macro-economic challenges militating against rapid transformation of the nation's economy. With a flood of unemployed graduates, Nigeria as a country will linger as a disoriented nation if she cannot effectively apprehend this social ordeal, which needs deliberate policies of state to arrest. Some developing economies like South Korea, Thailand, Israel, and Brazil amongst others have successfully taken decisive and bold actions to ameliorate the enigma of graduate unemployment by creating jobs for graduates.

Although, over the years, in Nigeria policies have been formulated to reduce the effect of graduate unemployment like the introduction of the N-Power programme, investments in Agriculture etc. but the incoherence's in the implementation of the programmes designed by the government for the reduction of graduate unemployment has become a concern. These programmes did not achieve the specified results due to poor implementation, corrupt practices, and other intervening factors in Nigeria (Chukwu and Igwe, 2012).

Further, as Ogege (2011) points out correctly:

Graduate unemployment in Nigeria has thrived over the years thanks to lack of national employment policy, sub-optimal quality of graduates, educational system not tailored and aligned to industry need and inappropriate educational curricula, poor political governance, poor setting of policy direction and inconsistent government policy. However, the Nigeria economy has not achieved any significant diversification after much campaign for one and therefore the country's tertiary education system has witnessed a ponderous admission overload of scholars, resulting into massive supply of higher education graduates. This existence of a lack of synergy between the churning out of graduates and employment opportunities underscore the complexity of the graduate unemployment issue in Nigeria. 
The various accomplishments reported by the National Directorate of Employment are mere paper policy indices that does not reflect the reality of high graduate unemployment the Nigerian society have had to grapple with. However, as a part of the remediable approaches to the reduction of graduate employment in Nigeria, Bassey and Atan (2012) and De Grauwe (2008) posited that:

todays' volatile labour market requires government's policy linking education to world of labor and developing university curricula content that transcend theoretical knowledge or specific technical skills but transversal skills that include reasoning and relations. Indeed, most university curricula in many developing nations especially in Nigeria bear little or no practical relevance to the requirements of their economy.

Poletaes and Robinson (2008) hence suggested that universities should engage in concrete partnership with employers of labour to develop a need based curriculum which will produce graduates with skills suitable for employment fulfillment. They also proffered a competency based educational scheme to blend theory and practice, thereby inculcating entrepreneurial and vocational acquisition skills in tertiary institution graduates. Some Nigerian scholars and researchers have also suggested various approaches to graduate unemployment reduction such as: empowerment of agricultural sector and encouragement of personal sector industries, (Ajayi, 2015) agriculture and tourism as priority sectors for employment generation, (Eneji, Mai-Laifa and Weiping, 2013), entrepreneurship development and risk capital promotion (Adawo, 2013), rendering mentoring roles to graduates to become self-employed (Chukwu and Igwe, 2012).

The methods posited above might be bottom up approach and innovative path to solving unemployment among university graduates, notwithstanding they should not be seen as perfect strategies. As Longe (Longe, 2017) points out:

Considering the state of hostile economic environment, weak governance, enfeebled institutional frame work and poor consumer spending power presently in Nigeria, overreliance on a number of the approaches could also be ill pre-disposed to reduction of graduate unemployment. Enforcing university graduates to become self-employed through the arrays of sublunary entrepreneurial and other puerile vocational acquisition programmes like bead making, carpentry, tailoring, barbing as being presently pursued in Nigerian universities could also be a waste of human capital. 


\section{The Need for Employability Skills}

Employers today are very much concerned with finding skilled and well trained workers rather than training unskilled ones. Consistent with Robinson (2000), employability skills are those basic skills necessary for getting, keeping and doing well on employment.

These are the talents, attitudes and actions that enable workers to work alongside their colleagues and supervisors and to take sound, critical decisions. Unlike occupational or technical skills, employability skills are generic in nature instead of job specific and cut across all industry types, business sizes, and job levels from the entry level worker to the senior-most position.

Robinson also discusses that for one to become a valuable employee, the individual must have the capacity to think critically, act logically, be ready to evaluate situations to form decisions, and to unravel problems. Robinson (2000, P 2) highlights employability skills in three categories (i) Basic Academic Skills: like reading, writing, arithmetic (ii) Higher Order Thinking: such as Reasoning, Creativity (iii) Personal Skills: such as Self-control, solidarity etc.

According to Adetokunbo (2009) a skill gap may be a significant gap between the needed skills and the current capabilities of the workforce in a corporation. Skill gap exists when the organization cannot grow or remain competitive in its industry because its employees do not have the proper skills to assist drive business results or support its strategies and goals. Adetokunbo (2009) posited that:

bridging the skill gaps isn't merely improving workers' competence in core fields like technology, engineering, science and arithmetic, but there are gaps too in non-technical areas like leadership, management and communication. Education with relevant syllabuses and training in specific areas play crucial roles in achieving rapid changes in updating technical and engineering skills. The ability to innovate, collaborate and compete, are the non-technical skills which are equally important employability skills. These manifest incompetence in people-management, human relations, language proficiency, etc. Good character traits 
like honesty, integrity, hard work, love, empathy, justice and fairness are intrinsic invaluable skills that contribute immensely to success. These skills oftentimes helps to sustain the operation of an organization where other technical skills are not adequate.

\section{The Need for Curriculum Review in Nigerian Higher Education}

The strength and therefore the level of development of any nation depends on the strength and development of her human resources. Efficient human resources are made via the education systems especially, education systems operated by such a nation. Central to an education system are the problems of curricular. Curriculum focused on skills development helps to foster national development and often times higher institutions of learning is a major medium through which individuals acquire required skills to function and be relevant within the society. The world today demands a skill-oriented education system.

The Federal Republic of Nigeria in her efforts to streamline education and skill acquisition and development formulated the National Policy on Education (NPE) which contains goals, status, modes of operation and processes of achieving the preset aims and objectives of higher education with clear statements on skills acquisition and development of higher institution students which includes industrial attachment, internship/teaching practice and other programmes through which necessary and relevant skills can be imparted in the potential graduates of higher education nonetheless the recommendations of the National Policy on Education has suffered from non-compliance and non-implementation of the policy statement.

Over the years in Nigeria, there has been an over-reliance on paper qualification as against the talents and can-do ability of a graduate. The outdated curriculum has made it difficult for these graduates to be employable and therefore requires that they're retrained to suit into various organizations. The knowledge attained through an obsolete or archaic curriculum is neither valued within the current dispensation of organizational development, nor capable of preparing these learners for future challenges or tasks. Unfortunately, these graduates feel otherwise as they see themselves as fit for the very best positions within the society believing that a well-polished office 
space should be their destination after their sojourn in their various higher institutions but unfortunately, the ingredients required to make them fit for these offices are lacking within the curriculum they had been subjected to for the amount of years spent studying.

The government owns public state and federal universities in Nigeria. Hence government has continued to be the most source of finance of higher institutions. Government has a role to play in improving the quality of higher education by ensuring that relevant funding policy is established for correct funding challenges faced by universities within the country. Government also needs to make sure relevant curriculum is implemented in universities and also seek to ensure such curriculum is consistently reviewed in line with market demands today and in anticipating the demands of the future. The university governing council or board of governors is charged with the role of ensuring continuous improvement in quality of university education through policy formulation and monitoring institutional performance. Additionally, Members of governing council should work as a team with external stakeholders in seeking continuous improvement and within the process of reviewing academic standards and quality in university education systems in Nigeria.

\section{Creation of Employment Opportunities for Graduates in Nigeria}

The alarming high rate of graduate unemployment has made it imperative to ensure that recommendations are raised in order to foster peace and development of Nigerian society and reduce the social unrest that comes as a result of a flood of unemployed graduates. The following recommendations are however raised so as to add to the poll of knowledge and to necessitate formation of policies by government agencies.

\section{- Infusion of Work Study Programme in University and Higher Education.}

Government should revisit and improve the educational system by blending Universities and higher institutions teaching with the ideology of work study programme. The ideology of work study can help to foster both theoretical knowledge and also practical experiences in the learner and at the same time the student while still in school is able to earn a stipend for living. 
The essence of the work study program will be to blend the theoretical information students receive in classroom together with the needed on field experience that allows the learner to be equipped with relevant requisite skills required for that learner to perform well by the time he/she graduates and also helps to increase the likelihood of students being employed as they would have gained experience on field throughout at least 50 percent of the number of years they spend in the university. It is suggested however that Universities and other higher institutions need to adjust their lectures time table rather than occupy the student for good 8 hours and more as obtainable in our higher institutions today, departments can be flexible in their timing to at least give room for students to be attached to a firm, an organization, an industry or ministry for internship depending on the area of discipline of the students.

\section{- Public and Private Organizations Should Embrace Corporate Social Responsibility.}

Government should encourage and perhaps raise a policy that mandates public and private organizations to setup programs to employ potential fresh graduates into their workforce as part of their corporate social responsibility. This approach will go a long way in reducing the challenge of graduate unemployment, however companies might find this strategy difficult to adopt as they cannot attest to the possibility of the graduates possessing enough skill to perform effectively in their organization. Hence, this is why the work study programme being infused into universities curriculum will help to bridge this gap making it easier for the organizations to employ the graduates considering that they would have worked with them as interns for a stipulated number of hours and over some years while they were still in the university hence this would allow them understand the techniques and methodologies of operations in such organization.

\section{- Adapting National Youth Service Corps as an Employment Route for Graduates.}

Statistics indicates that NYSC mobilizes about 300,000 graduates annually. According to the Director General of NYSC Shuaibu Ibrahim, no fewer than 300,000 graduates are mobilized annually for the National Youth Service Corps programme in its over 40 years of existence. The NYSC is a programme that allows graduates to serve the Nigerian nation at various locations in the country and at various department and fields such as the Education sector, Medicine, Science and Technology, Banking and Finance, Ministries etc. 
During this NYSC programme, graduates are actively involved with both the place of primary assignment duties as well as community development service in education, environmental and public health awareness, transport services, HIV and AIDs campaign etc and in return for this act of service and contribution to human life and community development they are usually rewarded with a monthly salary which elapses after 12 months. However, from this narrative what we have observed is that the NYSC is a programme through which graduates are given a temporary oneyear employment during their youth service and this employment is taken from them after 12 months rolling them back to the society where less jobs are available and where scarcity of employment opportunities exists. Rather than churn out graduates to the society after the National Youth Service period if the NYSC scheme can be absorbed into the National Directorate of Employment then Nigeria will be saving about 300,000 graduates from the menace of unemployment yearly. It therefore means that NYSC becomes the first ladder of Civil Service and once graduates are done with the National Youth Service Programme they can retain their jobs and be promoted while the next set of about 300,000 graduates gets ready to come into national youth service the following year. This routine will help in massive creation of jobs annually and will help to reduce the menace of graduate Unemployment nor employability as during the year of National Youth Service the graduates would have been more aligned with real work experiences. The benefits of this cannot be over emphasized as stated above aside helping to expand the creation of jobs annually it also would help to reduce the syndrome of square peg in a round hole as the graduates would only be employed to serve in their area of study in the University. Hence this helps to curb the issues of graduates who studied engineering having to be posted to schools to teach physics. Rather the one who has studied engineering should be posted for National Youth Service at the Engineering firms, Oil and gas etc and those who had studied teaching only should be posted to schools. This syndrome of square pegs in the round hole has been the case in Nigerian society and if we will utilize NYSC as a medium of ensuring employment for graduates then this challenge will become a thing of the past.

\section{Conclusion}

Numerous studies have established that university education, unless coupled with imparting of skills necessary for the youth to undertake socially and economically productive occupations, will merely remain qualification on paper. Nigeria in particular suffers from a higher education system 
that has unfortunately fostered unemployment and in the process given fillip to illegal and unethical options being resorted to by growing number of unemployed youth, whom the employment sector finds unemployable.

The recommendations raised in this article are keen on fostering peace and tranquility in Nigerian society and to ensure that education becomes embraced by all. This is because the assurance of getting a job after receiving higher education will help to spur people's interest for higher education and in turn help to develop the society, drastically reducing illiteracy and helping to save the future of our graduates. Crime rate in Nigeria will also witness a decline if the recommendations raised in this article can be harnessed to facilitate graduate employment and in turn peace, tranquility and development can become the order of the day.

\section{References}

Adawo, M. (2013); Graduate Unemployement in Nigeria. Entreprenurship and Venture Capital Nexus. Journal of Economic and Sustainable Development.4 (9) pp 75-81.

Adetokunbo, P. K. (2009). Bridging the skills gap in Nigeria: Framework for dialogue between universities and employers of labour. A Keynote Address Presented by Hon Minister of Labour and Productivity of the Federal Republic of Nigeria at the 24th Conference of the Association of Vice Chancellors of Nigerian Universities, University of Ilorin, Ilorin, Nigeria 2nd June.

Afolabi, F., Yusuf, M., \& Idowu, E. (2014). Ameliorating the Problem of Unemployment among Graduates through Relevant Functional and Sustainable University Education in Nigeria: InternationalReview of Social Sciences and Humanities. 7 (2) pp188-196.

Ajayi, J. (2015). Graduate Unemployment and Criminality in Ado-Ekiti, International Journal of Business Resources Management, 5(1), pp61-77.

Akintoye, I. (2008). Reducing Unemployment through the Informal Sector A case study of Nigeria. European Journal of Economics, Finance and Administrative Science 1(1), pp97-106.

Baku, M., Ashiagbor, I., Simon T., and Alfred, D. (2008). Graduate Unemployment in Ghana Possible Case of Poor Response of University Programme to the Demand of the Job Market: 
Report of the Educational Research Network for West Africa and Central Africa. ERNWACA Graduate Programme for Educational Research.

Balogun, K. (2016); Unemployment in Africa Paper Presented at African Transformation Forum organized by African Centre for Economic Transformation (ACET), April, 2016, Kigali, Rwanda.

Bassey, G. \& Atan, J. (2012). Labour Market Distortions and University Graduate Unemployment in Nigeria. Current Research Journal of Economic theory 4(3) pp67-76.

Chukwu, B. \& Igwe, A. (2012). Reducing Graduate Unemployment through Entrepreneurship Development. The Nigerian Experience, African Journal of Social Sciences, 2 (4) pp 139-152.

Dabalen, A., Oni, B. \& Adekola, O. (2000). Labour Market Prospects for University Graduates in Nigeria. Higher Education Management. 14 (1) pp1-36.

Eneji, M, Mai-Laifa, D. \& Weiping, S. (2013). Socio-Economic Impact of Graduate Unemployment in Nigeria and the Vision 20: 2020, International Journal of Development and Sustainability, 2 (1) pp148-176.

Longe, O. (2017). Graduate Unemployment in Nigeria: Causes, Consequences and Remediable Approaches. American International Journal of Contemporary Research.

National Bureau Statistics (2016). Unemployment and Underemployed Watch in Nigeria (Quarter 4) National Bureau of Statistic, Publication, Abuja, Nigeria. Pp: 63-73.

Ogege, S. (2011). Education and the Paradox of Graduate Unemployment. The Dilemma of Development in Nigeria. African Research Review, vol. 5 (1) No 18, January, pp 253-265.

Poletaes, M. and Robinson, C. (2008). Human Capital Specificity. Evidence from Dictionary of Occupational Titles. Journal of Labour Economics 2. 26 (3) pp 387-420.

Robinson, JP (2000). What are employability skills? The workplace 3(3) 1-3 September 2000 (ACES, 200).

Vanguard (2016) retrieved from https://www.vanguardngr.com/2017/04/nysc-mobilises-300000graduates-annually-dg/ 